\title{
Civiel schadeverhaal via het strafproces anno 2016
}

\author{
Verslag van een onderzoek naar de praktijk van de besluitvorming van de strafrechter ten \\ aanzien van de afdoening van de voeging benadeelde partij
}

\author{
Mr.dr.J.M. Emaus endr.R.B.S. Kool*
}

\begin{abstract}
1. Inleiding
De positie van slachtoffers in het strafproces staat vandaag de dag uitdrukkelijk op de politieke agenda. Sinds 1 juli 2016 is bijvoorbeeld het spreekrecht voor slachtoffers aanzienlijk verruimd. Vanaf dat moment is het bovendien voor nabestaanden van een persoon die door een opzettelijk veroorzaakt verkeersongeval om het leven is gekomen, mogelijk geworden om een beroep te doen op het Schadefonds Geweldsmisdrijven. ${ }^{1}$ Deze ter illustratie genoemde maatregelen waren beide door het huidige kabinet aangekondigd in de nota 'Recht doen aan slachtoffers' ter versterking van de positie van slachtoffers in het strafproces. ${ }^{2}$
\end{abstract}

Het kabinet heeft met de nota en de maatregelen een ontwikkeling voortgezet die reeds in de jaren tachtig is ingezet en met de invoering van de Wet Terwee een duidelijke verbetering bracht in de mogelijkheid voor slachtoffers om schade via het strafproces te verhalen. ${ }^{3}$ Dat civiele schadeverhaal heeft de afgelopen jaren, in de hiervoor geschetste bredere context

\footnotetext{
Mr. dr. J.M. Emaus is universitair docent Privaatrecht aan de Universiteit Utrecht en als onderzoeker verbonden aan de Utrechtse onderzoekscentra UCALL en RENFORCE, en zij is SIM Fellow. Dr. R.S.B. Kool is universitair hoofddocent Strafrecht aan de Universiteit Utrecht en als onderzoeker verbonden aan het Utrechtse onderzoekscentrum UCALL. Dit artikel is gebaseerd op onderzoek dat is uitgevoerd in samenwerking met (UCALL-)collega's Patrick Backers, François Kristen, Oscar Pluimer, Daan van Uhm en Emma van Gelder. Zie R.S.B. Kool, P. Backers, J.M. Emaus, F.G.H. Kristen, O.S. Pluimer, D.P. van Uhm \& E.M. van Gelder, Civiel schadeverhaal via het strafproces. Een verkenning van de rechtspraktijk en regelgeving betreffende de voeging benadeelde partij (UCALL, deel 8), Den Haag: Boom juridisch 2016.

1. Wet van 14 april 2016 tot wijziging van het Wetboek van Strafvordering ter aanvulling van het spreekrecht van slachtoffers en nabestaanden in het strafproces en wijziging van de Wet schadefonds geweldsmisdrijven ter uitbreiding van de mogelijkheid van uitkering aan nabestaanden, Stb. 2016, 160

2. Ministerie van Veiligheid en Justitie, Recht doen aan slachtoffers. Visiedocument, Den Haag: Ministerie van Veiligheid en Justitie 2013, www. rijksoverheid.nl/venj.

3. Wet van 23 december 1992 tot aanvulling van het Wetboek van Strafrecht, het Wetboek van Strafvordering, de Wet voorlopige regeling schadefonds geweldsmisdrijven en andere wetten met voorzieningen ten behoeve van slachtoffers van strafbare feiten (Wet Terwee), Stb. 1993, 29.
}

waarin aandacht is voor de versterking van de positie van het slachtoffer in het strafproces, belangrijke ontwikkelingen doorgemaakt. Eén daarvan betreft de aanpassing in 2010 van het criterium voor ontvankelijkheid van de benadeelde partij. ${ }^{4}$ Tot dat moment gold dat de vordering van de benadeelde partij 'eenvoudig van aard' diende te zijn. De aanpassing bracht het nieuwe criterium van de 'onevenredige belasting'; een vordering van de benadeelde partij kan sindsdien door de strafrechter (geheel of ten dele) niet-ontvankelijk worden verklaard als de behandeling daarvan een onevenredige belasting van het strafgeding oplevert. ${ }^{5}$ Andere ontwikkelingen betreffen de invoering van de Voorschotregeling in $2011^{6}$ en de publicatie van de Handleiding voor de strafrechtspraktijk met uitgebreide aandacht voor de vordering benadeelde partij in 2013. ${ }^{7}$

Deze ontwikkelingen op het gebied van het civiele schadeverhaal zijn aanleiding voor het recente onderzoek waarvan in dit artikel verslag wordt gedaan en dat de vraag behandelt hoe de praktijk van de besluitvorming van de strafrechter ten aanzien van de afdoening van de voeging benadeelde partij in het strafproces er anno 2016 uitziet. Het is verricht in opdracht van het Wetenschappelijk Onderzoek- en Documentatiecentrum (WODC), op verzoek van de Directie Beschermen, Aanpakken en Voorkomen, Cluster Slachtofferbeleid van het ministerie van Veiligheid en Justitie, en sluit aan op eerdere onderzoe-

4. Wet van 17 december 2009 tot wijziging van het Wetboek van Strafvordering, het Wetboek van Strafrecht en de Wet schadefonds geweldsmisdrijven ter versterking van de positie van het slachtoffer in het strafproces, Stb. 2010, 1.

5. Art. 361 lid 3 Sv.

6. Besluit van 24 juli 2010 , houdende vaststelling van het Uitvoeringsbesluit voorschot schadevergoedingsmaatregel, Stb. 2010, 311.

7. J. Candido, M. Hoendervoogt, P. van Dam \& M. Gest, Slachtoffer en de rechtspraak. Handleiding voor de strafrechtspraktijk, Den Haag: Raad voor de rechtspraak 2013. 
ken naar civiel schadeverhaal door slachtoffers van strafbare feiten. ${ }^{8,9}$

Dit artikel start met een introducerende paragraaf waarin het wettelijk kader wordt geschetst (par. 2). Daarna volgt een korte beschrijving van de door de onderzoekers gekozen aanpak (par. 3), gevolgd door een weergave van bevindingen op grond van het verrichte dossieronderzoek en de afgenomen interviews (par. 4). In de uitleiding (par. 5) wordt een en ander samengevat.

\section{Wettelijk kader}

Artikel 51f van het Wetboek van Strafvordering (Sv) biedt de benadeelde wiens schade het rechtstreeks gevolg is van een strafbaar feit de mogelijkheid om zich voor zijn vordering tot schadevergoeding te voegen in het strafproces. Het tweede lid van die bepaling voegt toe dat als deze persoon ten gevolge van het strafbare feit is overleden, zijn erfgenamen zich kunnen voegen voor de door hun onder algemene titel verkregen vordering, alsook de personen genoemd in artikel 6:108 lid 1 en 2 van het Burgerlijk Wetboek (BW) voor de daargenoemde vorderingen. De voeging gebeurt volgens artikel $5 \mathrm{lg}$ lid $3 \mathrm{~Sv}$ uiterlijk voor het requisitoir door de officier van justitie ter terechtzitting. Dat kan aldus mondeling tijdens de zitting, maar liever voegt de benadeelde partij zich reeds vóór de terechtzitting door middel van het aan hem toegezonden voegingsformulier, zoals beschreven in artikel $5 \mathrm{lg}$ lid $1 \mathrm{~Sv}$.

In de regel wordt bij toewijzing van een civiele vordering in een strafrechtelijke procedure ook de zogenaamde schadevergoedingsmaatregel opgelegd. De schadevergoedingsmaatregel houdt de verplichting in om de schadevergoeding ten behoeve van de (direct) benadeelde of nabestaande aan de Staat te betalen, die deze vervolgens na ontvangst onverwijld aan de benadeelde uitkeert. De maatregel neemt de schadevergoedingsgerechtigde de last uit handen om de vergoeding bij de schadeveroorzaker te innen en brengt die onder bij het Centraal Justitieel Incassobureau (CJIB). De bevoegdheid tot oplegging

8. In het bijzonder S. van Wingerden, M. Moerings \& J. van Wilsem, De praktijk van schadevergoeding voor slachtoffers van misdrijven, Den Haag: WODC 2007. En ook R.S.B. Kool, M.R. Hebly, D.P. van Uhm, L. Orvini, C.R.R. Loeve \& I. Giesen, Schadeverhaal na een strafbaar feit via de kantonrechter, Den Haag: Boom Juridische uitgevers 2014; J.D.M. van Dongen, S.D. Lindenbergh \& M.R. Hebly, Je hebt geluk als je van een pauw mag plukken. Ervaringen van slachtoffers van strafbare feiten met het verhalen van hun schade, Rotterdam: Erasmus Universiteit Rotterdam 2013; W.M. Schrama \& T. Geurts, Civiel schadeverhaal door slachtoffers van delicten. De rol van de civiele procedure: gebruik, knelpunten en oplossingsrichtingen, Den Haag: WODC 2012; R.S.B. Kool \& M.M. Moerings, De Wet Terwee. Evaluatie van juridische knelpunten, Deventer: Gouda Quint 2001.

9. Zie over civiel schadeverhaal in dit tijdschrift ook E.S. Engelhard, M.R. Hebly \& I. van der Zalm, De shockschadevordering in het strafproces, TVP 2015, p. 87-96; A.H. Sas, De zaak Robert M. in cassatie. De ouders van de slachtoffers als benadeelde partij in het strafproces: hun verplaatste schade en proceskosten, TVP 2015, p. 8-15; F.M. Ruitenbeek-Bart \& A.J.J.G. Schijns, De schadeclaim van het slachtoffer van strafbare feiten: bruggenbouwer tussen twee rechtsgebieden, TVP 2014, p. 38-47; J.D.M. van Dongen, M.R. Hebly \& S.D. Lindenbergh, Schadeverhaal na misdrijven: ervaringen van slachtoffers, TVP 2014, p. 1-7. van de maatregel is de rechter in artikel $36 \mathrm{f} \mathrm{lid} 1$ van het Wetboek van Strafrecht $(\mathrm{Sr})$ gegeven. De oplegging is overigens niet van de toewijzing van schadevergoeding aan een gevoegde benadeelde afhankelijk gesteld, aldus de Hoge Raad, onder de overweging:

'Uit de bewoordingen alsmede de geschiedenis van de totstandkoming van art. 36f $\mathrm{Sr}$ volgt dat de in die bepaling bedoelde maatregel een strafrechtelijke sanctie is die los van de beslissing in de voegingsprocedure kan worden opgelegd indien en voor zover de verdachte jegens een slachtoffer naar burgerlijk recht aansprakelijk is voor de schade die door het strafbare feit is toegebracht. Noch uit de tekst van de wet, noch uit de wetsgeschiedenis vloeit voort dat de mogelijkheid tot het opleggen van die schadevergoedingsmaatregel afhankelijk is gesteld van de opeisbaarheid van het vorderingsrecht van het slachtoffer. ${ }^{.10}$

In lid 7 van artikel $36 \mathrm{f} \mathrm{Sr}$ is verder nog de zogenaamde voorschotregeling opgenomen. Die regeling houdt in dat de Staat het restant van de nog niet door de veroorzaker van een misdrijf betaalde vergoeding voorschiet, indien de veroorzaker niet of niet geheel aan zijn verplichting heeft voldaan binnen acht maanden na het onherroepelijk worden van het vonnis of arrest waarbij de schadevergoedingsmaatregel is opgelegd. ${ }^{11} \mathrm{Bij}$ gewelds- en zedenmisdrijven geldt geen limiet, bij de andere misdrijven is het voorschot niet hoger dan $€ 5000 .^{12}$

Een voordeel voor de benadeelde partij die via het strafproces tracht schade te verhalen, is gelegen in de bewijslevering, aangezien de benadeelde partij, aldus de Hoge Raad, 'tot staving dier vordering mag medewerken, wat in het strafgeding als wettig bewijsmiddel is toegelaten, hetgeen in overeenstemming is met den aard der vordering als accessoir van het strafgeding. ${ }^{13}$ Daarbij moet anderzijds worden bedacht dat de benadeelde in zijn vordering ook aan belangrijke beperkingen onderhevig is, aangezien artikel 334 lid 1 Sv bepaalt dat de benadeelde partij 'tot het bewijs van de ten gevolge van het strafbare feit geleden schade (...) geen getuigen of deskundigen kan aanbrengen'. Een ander voordeel is dat, anders dan in een civiele procedure, geen kosten voor griffierechten verschuldigd zijn.

Een belangrijke drempel voor benadeelde partijen die zich voor hun schadevergoeding voegen in het strafproces, ligt besloten in artikel $361 \mathrm{~Sv}$. Dat artikel regelt de ontvankelijk-

10. HR 13 juli 2010, NJ 2010/459, r.o. 3.4. Zie ook Candido e.a. 2013, p. 165.

11. Deze regeling is tot 1 september 2016 van toepassing geweest op slachtoffers van ernstige gewelds- en zedenmisdrijven en art. 6 WVW. Vanaf genoemde datum is de regeling van toepassing op alle misdrijven, zij het dat het voorschot is gemaximeerd tot $€ 5000$; voorts moet de schadevergoedingsmaatregel waarop het voorschot is gebaseerd, zijn opgelegd na 1 januari 2016. Zie art. 1 (oud) Uitvoeringsbesluit voorschot schadevergoedingsmaatregel. En ook Aanhangsel Handelingen II 2015/16, 1056.

12. Art. 2 Uitvoeringsbesluit voorschot schadevergoedingsmaatregel.

13. HR 30 oktober 1938, NJ 1939/258. Zie ook Candido e.a. 2013, p. 108. 
heid van de benadeelde partij. Voor ontvankelijkheid van de benadeelde partij is een veroordeling vereist met daaraan verbonden oplegging van straf en/of maatregel, alsook dat aan de benadeelde rechtstreeks schade is toegebracht door het bewezen verklaarde feit of een ad informandum tenlastegelegd feit. Daarbij geldt, aldus de Hoge Raad, 'dat de concrete omstandigheden van het geval bepalend zijn voor de beantwoording van de vraag of voldoende verband bestaat tussen het bewezenverklaarde handelen'. ${ }^{14}$ Het derde lid van genoemd artikel bepaalt voorts dat de rechter tot niet-ontvankelijkheid kan beslissen, indien de behandeling van de vordering, naar zijn oordeel, een onevenredige belasting van het strafgeding oplevert.

De inhoudelijke beoordeling van de vordering, tot slot, gebeurt in beginsel op grond van de artikelen 6:162 jo. 6:95 e.v. BW. Daarbij geldt in de context van de strafprocedure in de eerste plaats dat, indien de rechter beslist tot veroordeling van de verdachte voor het strafbare feit dat de benadeelde rechtstreeks schade heeft toegebracht, de verdachte aldus onrechtmatig, want in strijd met de wet, heeft gehandeld. ${ }^{15}$ Tegelijkertijd kan, met de strafrechtelijke veroordeling, de daad aan de dader worden toegerekend op grond van schuld. ${ }^{16}$

De vraag naar relativiteit van de geschonden norm hangt nauw samen met het hiervoor genoemde criterium voor ontvankelijkheid, namelijk dat de schade het rechtstreeks gevolg moet zijn van het bewezen verklaarde feit of ad informandum tenlastegelegde feit als in artikel $361 \mathrm{~Sv}$. A-G Langemeijer benoemt als verschil met de civiele procedure nog dat een benadeelde onder artikel 6:163 BW in een civiele procedure vrij is in de keuze van de norm die aan artikel 6:163 BW wordt getoetst, zodat de beperking die daarvoor in de context van de civiele voeging geldt, maakt dat de begrenzing door de relativiteit sneller in beeld komt:

'In een procedure bij de burgerlijke rechter is de eisende partij vrij om zelf de grondslag van haar vordering te bepalen: de "geschonden norm" kan een geschonden strafbepa-

14. HR 22 april 2014, NJ 2014/256; HR 5 juli 2016, NJ 2016/335.

15. A.S. Hartkamp \& C.H. Sieburgh, Mr. C. Assers Handleiding tot de beoefening van het Nederlands burgerlijk recht. 6. Verbintenissenrecht. Deel IV. De verbintenis uit de wet, Deventer: Kluwer 2015, nr. 44. Zou de vordering tot schadevergoeding aan de civiele rechter worden voorgelegd, dan geldt dat, indien de strafrechter dan reeds heeft beslist tot veroordeling van de verdachte, het onherroepelijke, op tegenspraak gewezen (straf)vonnis in de civiele procedure ex art. $161 \mathrm{Rv}$ dwingend bewij van het in het vonnis bewezen verklaarde feit oplevert. Tegenbewijs staat overigens vrij, aldus art. 151 lid $2 \mathrm{Rv}$. De dwingende bewijskracht van het strafrechtelijk vonnis geeft de benadeelde in een civiele procedure een voordeel bij het bewijzen van de (vermeende) onrechtmatige gedraging door de gedaagde, voor zover die gedraging, aldus Asser, correspondeert met het in het strafvonnis bewezen verklaarde feit. Zie W.D.H Asser, Asser Procesrecht. Deel 3. Bewijs, Deventer: Kluwer 2012, nr. 260. Hierbij moet worden bedacht dat, indien de vordering in de strafprocedure wordt behandeld, reeds uit de beoordeling van de ontvankelijkheid voortvloeit dat aannemelijk is dat de schadeveroorzakende gedraging correspondeert met het tenlastegelegde feit. Anders zou een kennelijke niet-ontvankelijkheid dienen te volgen (art. $333 \mathrm{~Sv}$ ).

16. Art. 6:162 lid 3 BW. ling zijn (handelen in strijd met de wet), maar ook een regel van ongeschreven recht (handelen in strijd met hetgeen volgens ongeschreven recht in het maatschappelijk verkeer betaamt, art. 6:162 $\mathrm{BW}$ ) of het niet nakomen van een verplichting uit overeenkomst. Wanneer de benadeelde partij ervoor kiest, zich te voegen in een door de officier van justitie aangebrachte of nog aan te brengen strafprocedure, kan zij niet op iedere door haar gewenste grondslag een vordering instellen. De inhoud van de telastelegging wordt door de officier van justitie bepaald. De benadeelde partij lift, om zo te zeggen, mee in de wagen die door de officier van justitie in beweging is gezet, maar zit niet aan het stuur. In het strafproces is de "geschonden norm" van art. 6:163 BW: de wettelijke bepaling die met straf is bedreigd. De onrechtmatige daad die aan de voeging ten grondslag kan liggen is dus het handelen in strijd met de strafrechtelijke norm waarvan de overtreding ten laste is gelegd. Naarmate de grondslag van de vordering beperkter is, komt het relativiteitsbeginsel eerder in beeld. ${ }^{17}$

Een uitspraak van de Rechtbank Limburg kan de begrenzing door de tenlastelegging in de context van het strafproces verduidelijken. Aan verdachte werd (onder meer) het gebruikmaken van een niet op zijn naam gesteld Nederlands paspoort ten laste gelegd. ${ }^{18}$ Het paspoort was van 'slachtoffer 3 ', dat zich als benadeelde partij in het strafproces had gevoegd en vergoeding vorderde van boetes van de NS, kosten van een nieuw paspoort en immateriële schade. De rechtbank overwoog echter dat het beschermd belang van het tenlastegelegde feit is

'1) het openbaar vertrouwen. Dat wil zeggen: het vertrouwen dat burgers in het maatschappelijke verkeer in de juistheid van bepaalde geschriften moeten kunnen stellen, en 2) het tegengaan van benadeling van overheid, bedrijven en burgers door gebruik van valse/vervalste documenten. ${ }^{19}$

De gevorderde vergoeding, aldus de rechtbank, zag niet op de schade die in dat kader was opgelopen en de benadeelde partij was aldus niet-ontvankelijk in haar vordering. ${ }^{20}$ Alhoewel het ons inziens zeer wel denkbaar is dat jegens deze benadeelde partij onrechtmatig is gehandeld, strekte de in de strafprocedure centraal gestelde norm niet tot bescherming van 'slachtoffer 3'.

$\mathrm{Na}$ vaststelling van aansprakelijkheid komt de rechter toe aan de bepaling van de omvang van de vergoedingsverplichting. Voor de civiele voeging geldt, zoals hierna verder wordt uitgelegd, dat in die fase een belangrijk gevaar voor onevenredige belasting van het strafgeding schuilgaat. ${ }^{21}$

\footnotetext{
17. Concl. A-G Langemeijer voor HR 19 juni 2015, RvdW 2015/772.

18. Rb. Limburg 10 februari 2015, ECLI:NL:RBLIM:2015:1042.

19. Rb. Limburg 10 februari 2015, ECLI:NL:RBLIM:2015:1042, r.o. 6

20. Rb. Limburg 10 februari 2015, ECLI:NL:RBLIM:2015:1042, r.o. 6.

21. Zie par. 4.2 en 4.3
} 


\section{Aanpak}

De vraag naar de praktijk van de besluitvorming van de strafrechter ten aanzien van de civiele voeging anno 2016 is door de onderzoekers in vier fasen beantwoord. In de eerste fase is een inventarisatie gemaakt van het voortraject - de fase waarin de voeging wordt voorbereid. ${ }^{22}$ Dat is gebeurd door middel van een desk study gecombineerd met semigestructureerde interviews met medewerkers van Slachtofferloketten en werkbezoeken aan het Slachtofferloket Midden-Nederland en het Slachtofferloket Amsterdam. Voor de interviews zijn respondenten gevonden die actief (en soms ook beleidsmatig) in het voortraject werkzaam zijn.

In de tweede fase zijn trendgegevens verzameld voor de periode 2010-2014 en is dossieronderzoek verricht in zaken afgedaan in 2014 om te achterhalen hoe vaak civiel schadeverhaal plaatsvindt en succesvol is en, meer in het bijzonder, welke factoren van invloed zijn op de ontvankelijkheid van de benadeelde partij. ${ }^{23}$ Daartoe zijn in totaal 217 dossiers onderzocht, die op basis van vier criteria waren geselecteerd, te weten: (1) reguliere strafzaken, (2) delictscategorieën mishandeling, diefstal, vernieling en openlijke geweldpleging, (3) afgedaan door meervoudige kamer en (4) arrondissementen Amsterdam, Midden-Nederland, Oost-Nederland, Noord-Nederland, Limburg en Rotterdam. Ten behoeve van het onderzoek is een variabelenlijst opgesteld met factoren die van invloed kunnen zijn op de beslissing ten aanzien van de civiele vordering. ${ }^{24}$ Tot die variabelen horen bijvoorbeeld de aard van de schade waarvan vergoeding wordt gevorderd, de hoogte van de gevorderde vergoeding, de aanwezigheid van de benadeelde partij ter zitting, het voeren van verweer namens de gedaagde en het al of niet aanwezig zijn van het (standaard)schadeformulier. De voor het onderzoek ontworpen database is in SPSS geladen en de data zijn met behulp van dat programma statistisch geanalyseerd.

Fase drie van het onderzoek betrof de verkenning van de zittingspraktijk door middel van semigestructureerde interviews met personen die beroepsmatig betrokken zijn bij de besluitvorming over de civiele voeging, te weten: rechters (9), officieren van justitie (4), advocaten-generaal $(3)^{25}$ en advocaten die benadeelde partijen bijstaan (7). ${ }^{26}$ Ten behoeve van de interviews is (per beroepsgroep) een vragenlijst opgesteld die vooraf ter voorbereiding aan respondenten is toegestuurd. ${ }^{27}$ Zo kon de beperkte tijd die voor het interview met respondenten in persoon beschikbaar was optimaal worden benut en was er

22. Kool e.a. 2016, p. 26-27

23. Kool e.a. 2016, p. 27-34.

24. De variabelenlijst is als bijlage bij het eindrapport opgenomen. Zie Kool e.a. 2016, p. 335-340.

25. Voor het gemak van de lezer wordt hierna nog enkel gesproken over 'officier(en) van justitie'. Steeds wordt bedoeld: officieren van justitie en advocaten-generaal.

26. Kool e.a. 2016, p. 34-36.

27. De vragenlijsten zijn als bijlage bij het eindrapport opgenomen. Zie Kool e.a. 2016, p. 343-359. ook ruimte om, zo daartoe aanleiding was, vervolgvragen te stellen.

In de vierde fase van het onderzoek stond de vraag centraal of, en zo ja hoe, het civiele schadeverhaal zou kunnen worden aangepast, opdat in de toekomst meer vorderingen door de rechter in behandeling worden genomen. ${ }^{28}$ Het antwoord op die vraag is niet alleen gezocht in wat daarover in de literatuur en interviews kon worden gevonden. Er is ook een sterktezwakteanalyse uitgevoerd voor drie procedurele voorzieningen (schadestaatprocedure als in art. 612 van het Wetboek van Burgerlijke Rechtsvordering ( $\mathrm{Rv})$, voorzittersbeschikking als in art. 258a Sv en splitsing van het strafproces als in art. 36e $\mathrm{Sr}$ ) en één materieelrechtelijke (tarifering, ook: normering ${ }^{29}$ ). Voor elke figuur is voor vier basisposities met verschillende soorten belemmeringen voor het civiele schadeverhaal getoetst aan acht maatstaven, te weten: (1) het accessoire karakter van de vordering, (2) het belang van een gewaarborgd strafproces (in het bijzonder de onschuldpresumptie), (3) de ruimte voor wederzijdse betwisting, (4) berechting binnen redelijke termijn, (5) het recht op een gewaarborgd proces voor het slachtoffer, (6) het optimaliseren van schadeloosstelling van de benadeelde partij, (7) executieve voordelen voor de benadeelde partij, en (8) de werklast (uitvoeringslast) voor de betrokken organisaties.

De aandacht is hierna gericht op de uitkomsten in de tweede en derde fase. Voor het voortraject wordt hier kort volstaan met de opmerking dat de inrichting daarvan aanzienlijk is veranderd ten opzichte van het voortraject ten tijde van het onderzoek door Van Wingerden en anderen. De Slachtofferloketten zijn gecentraliseerd, wat tot stroomlijning in de voorbereidingsfase heeft geleid. Tegelijkertijd is er in interviews melding gemakkt van capaciteitsgebrek bij Slachtofferhulp Nederland en wordt de kwaliteit van de vorderingen die met hulp van Slachtofferhulp Nederland zijn opgesteld, wisselend beoordeeld. De inzet op vroegtijdige voeging, tot slot, zorgt voor problemen waar zo'n vroegtijdige voeging niet mogelijk is. Digitale processen zijn zo ingericht dat er een reëel risico bestaat dat een slachtoffer niet bekend wordt bij de autoriteiten. Een vroegtijdige opstelling van een slachtoffer als benadeelde partij zou verder niet in lijn zijn met de realiteit van de slachtofferervaring.

Wat de verkenning van de rechtsfiguren in fase vier betreft verdient het hier in elk geval kort opmerking dat de verkenning niet heeft geleid tot de aanwijzing van één of meer figuren die als beste uit de bus komen. Voor alle figuren is beschreven welke aanknopingspunten ze bieden voor oplossingen voor in dit onderzoek geconstateerde problemen, in het bijzonder dat van het spanningsveld tussen het civiele schadeverhaal en de bewaking van het gewaarborgde proces voor de verdachte. En ze zijn als gezegd aan een aantal maatstaven getoetst. Als resultaat daarvan geldt dat alle vier de figuren

28. Kool e.a. 2016 , p. 36.

29. Lindenbergh 2014. 
goed scoren op de maatstaven van het gewaarborgde proces (voor verdachte én benadeelde), de mogelijkheid tot wederzijdse betwisting en de optimalisering van de schadeloosstelling. Ze scoren tegelijkertijd slecht op de maatstaven van de redelijke termijn (tarifering uitgezonderd) en de werklast voor de betrokken organisaties.

Voor de meer uitgebreide uiteenzetting van resultaten ten aanzien van het voortraject en van de wetenschappelijke zoektocht naar alternatieven wordt verwezen naar het eindrapport. $^{30}$

\section{Bevindingen}

\subsection{De ontwikkeling van de civiele voeging over de} afgelopen jaren, in het bijzonder van de ontvankelijkheid

De vraag naar de ontwikkeling van de ontvankelijkheid over de afgelopen jaren is in de eerste plaats beantwoord aan de hand van trendgegevens. ${ }^{31}$ Voorts is in de interviews aan respondenten voorgelegd of zij menen dat de wijziging van het criterium voor ontvankelijkheid (van eenvoudig-van-aard-criterium naar criterium van onevenredige belasting) het gewenste effect heeft gehad.

Uit de trendgegevens over de jaren 2010-2014 blijkt in de eerste plaats dat het aantal strafzaken met $11,2 \%$ is gedaald, ${ }^{32}$ terwijl het aantal voegingen met een kleine daling van $2,4 \%$ relatief stabiel is gebleven. Dat levert een lichte stijging van voegingen in strafzaken op, van $16,5 \%$ in 2010 naar $18,1 \%$ in 2014. Binnen het relatief stabiele aantal zaken waarin jaarlijks wordt gevoegd, vindt een duidelijke verschuiving plaats ten aanzien van de ontvankelijkheid (zie tabel 1). ${ }^{33}$ Terwijl in 2010 nog 32,3\% van de vorderingen niet-ontvankelijk werd verklaard, is dat in vier jaar tijd langzaam afgenomen tot nietontvankelijkheid van $16,6 \%$ van de vorderingen in 2014 . Tegelijkertijd steeg het aantal zaken in de categorie gedeeltelijk ontvankelijk / ontvankelijk van 29,8\% naar 59,7\%. In deze categorie zijn zaken opgenomen die door niet bij dit onderzoek aansluitende registratie niet eenduidig ofwel onder 'gedeeltelijk ontvankelijk' of 'ontvankelijk' konden worden ingedeeld. Het verdient daarbij opmerking dat zowel in de categorie 'ontvankelijk' als in de categorie 'gedeeltelijk ontvankelijk' een daling is waar te nemen in de onderzochte periode (van $30,3 \%$ naar $19,2 \%$ respectievelijk van $7,8 \%$ naar $4,5 \%$ ). ${ }^{34}$

In de interviews is aan alle respondenten de vraag voorgelegd of de wijziging van het ontvankelijkheidscriterium naar de indruk van respondenten het daarmee beoogde effect heeft gehad, te weten een ruimere toepassing van het civiele schade-

30. Kool e.a. 2016, hoofdstuk 4 en 7.

31. Kool e.a. 2016, p. 39-46.

32. S.N. Kalidien (red.), Criminaliteit en rechtshandhaving 2015. Ontwikkelingen en samenhangen, Den Haag: CBS/WODC/Raad voor de rechtspraak 2016, tabel 6.1.

33. Tabel uit Kool e.a. 2016, p. 41.

34. Kool e.a. 2016, p. 42. verhaal. ${ }^{35}$ De meeste rechters menen dat dit niet zo is. Die indruk wordt onder meer gekoppeld aan het achterwege blijven van civiele kennis bij de rechters in het algemeen. Een rechter stelt: 'Dan kan je het criterium wel wijzigen, maar als de civiele kennis van de strafrechters niet beter wordt .... Dan blijft het gewenste effect uit, aldus deze rechter. ${ }^{36}$ Er wordt ook aan de persoonlijke kennis gerefereerd om aan te geven dat die uiteindelijk doorslaggevend is. Het moet voor de rechter, anders gezegd, niet 'te moeilijk' zijn om de vordering te beoordelen. Te moeilijk is bijvoorbeeld (al snel) de berekening van arbeidsvermogensschade. ${ }^{37}$

Maar er zijn ook rechters die wel geloven dat er iets is veranderd. Zo vertelt een rechter dat bijvoorbeeld de hoogte van de gevorderde vergoeding voorheen goed aanleiding kon zijn voor de beslissing om de vordering niet-ontvankelijk, want niet eenvoudig van aard, te verklaren, terwijl de hoogte van de gevorderde vergoeding tegenwoordig, onder het nieuwe criterium, minder vaak aanleiding zou zijn om niet-ontvankelijk te verklaren. Een andere rechter stelt 'toch best vaak ingewikkelde vorderingen' te beoordelen; 'in beginsel willen we de vordering toch wel gewoon beoordelen' ${ }^{38}$

Officieren van justitie menen dat het nieuwe ontvankelijkheidscriterium niet het beoogde effect heeft gehad. Zij merken daarbij op dat er overigens wel iets is veranderd, maar verklaren dat door 'de tijdgeest' en 'besefvorming'. Als resultaat, aldus een officier, 'wordt [incidenteel] wel eens een keer een vordering toegewezen die je met het oude criterium van tafel zou vegen'. ${ }^{39}$ Voor de meeste advocaten geldt ook dat zij weliswaar een verandering zien, maar een die wellicht niet per se aan de verandering van het criterium kan worden toegeschreven. Enkele advocaten zijn minder positief en merken op dat er nog best veel rechters 'van de oude stempel' zijn, die zich er gemakkelijk van afmaken. ${ }^{40}$

\subsection{Factoren van invloed op de ontvankelijkheidsbeslissing: dossieronderzoek}

\subsubsection{Het dossieronderzoek}

Verschillende factoren kunnen van invloed zijn op de beslissing of al of niet sprake is van een onevenredige belasting van het strafgeding. Daarbij valt te denken aan kenmerken van de vordering (aard en omvang van de gevorderde vergoeding), maar ook aan het al of niet voeren van verweer door de dader, diens aanwezigheid, en de hulp die de benadeelde partij bij de voorbereiding van de vordering heeft gehad. In dit onderzoek is getracht te achterhalen welke van die hypothetisch van invloed zijnde factoren in de praktijk daadwerkelijk een rol spelen. Daartoe is in de eerste plaats dossieronderzoek ver-

\footnotetext{
35. Zie Kool e.a. 2016, p. 343-359.

36. Kool e.a. 2016, p. 171.

37. Kool e.a. 2016, p. 172.

38. Kool e.a. 2016, p. 172.

39. Kool e.a. 2016, p. 170-171

40. Kool e.a. 2016, p. 174.
} 
Tabel 1 Trendgegevens van 2010 tot en met 2014 betreffende de ontvankelijkheid van de benadeelde partij bij civiele vorderingen in het strafproces

\begin{tabular}{lrrrrr}
\hline & $\mathbf{2 0 1 0}$ & $\mathbf{2 0 1 1}$ & $\mathbf{2 0 1 2}$ & $\mathbf{2 0 1 3}$ & $\mathbf{2 0 1 4}$ \\
\hline Aantal zaken & 18.180 & 17.264 & 18.045 & 18.321 & 17.738 \\
Ontvankelijkheid benadeelde partij & & & & & \\
Ontvankelijk & $30,3 \%$ & $28,4 \%$ & $25,9 \%$ & $22,8 \%$ & $19,2 \%$ \\
Gedeeltelijk ontvankelijk & $7,8 \%$ & $6,5 \%$ & $6,0 \%$ & $5,2 \%$ & $4,5 \%$ \\
Niet-ontvankelijk & $32,2 \%$ & $23,5 \%$ & $21,1 \%$ & $18,9 \%$ & $16,6 \%$ \\
Gedeeltelijk ontvankelijk/ontvankelijk* & $29,8 \%$ & $41,7 \%$ & $46,9 \%$ & $53,1 \%$ & $59,7 \%$ \\
\hline
\end{tabular}

${ }^{*}$ Deze categorie bestaat uit ontvankelijk en gedeeltelijk ontvankelijk verklaarde zaken. Om een adequate verdeling van de data uit de RAC-min te kriigen is de afdeling SIBa van het WODC gevraagd een (her)indeling te maken waarin de drie gehanteerde categorieën worden aangehouden (namelijk: ontvankelijk, gedeeltelijk ontvankelijk en niet-ontvankelijk). Daarbij bleek dat de categorie van schadevergoedingsmaatregel niet eenduidig ingedeeld kon worden in ontvankelijk of gedeeltelijk ontvankelijk door een manco van specificatie bij de registratie. Voor de volledigheid van het trendbeeld is deze categorie wel meegenomen bij de analyse, maar opgenomen als aparte vierde categorie, 'gedeeltelijk ontvankelijk / ontvankelijk', om eventuele contaminatie te voorkomen.

richt. De opzet van dat onderzoek is reeds in paragraaf 2 kort toegelicht. Bij de uitkomsten van dit onderzoek moet worden vooropgesteld dat de dossiers niet consistent gevuld waren, zodat niet steeds alle variabelen konden worden ingevuld. Dit heeft de kans op het vinden van verbanden of verschillen verkleind. Dat neemt niet weg dat het mogelijk is geweest de onderzoeksvragen te beantwoorden en de volgende bevindingen te presenteren. ${ }^{41}$

\subsubsection{Kenmerken vordering vergoeding vermogensschade} Voor de vorderingen ter zake van materiële schade kan op grond van het dossieronderzoek in de eerste plaats het volgende worden gezegd. Materiële schadeposten hadden het vaakst betrekking op apparaten, inkomstenderving, braak- of herstelschade, reiskosten, geld en kleding. Voor het opvoeren van de laatste post (kleding) is een positief verband vastgesteld met de toewijzing van de vordering. Het aantal door benadeelde opgevoerde materiële schadeposten heeft geen negatief effect op de ontvankelijkheid, terwijl (anderzijds) bij een toename van het aantal materiële schadeposten de kans op toewijzing groter wordt. ${ }^{42}$ De totale hoogte van de gevorderde vergoeding ter zake van materiële schade blijkt niet van invloed op de toewijzing van de vordering. ${ }^{43} \mathrm{~W}$ at verder opvalt is dat het Openbaar Ministerie, bij advies tot toewijzing, in de regel een significant lager bedrag adviseert (gemiddeld $€ 396$ minder) en de rechter vervolgens significant lager dan het advies toewijst (gemiddeld $€ 620$ minder). ${ }^{44}$ De gemiddelde hoogte van de toewijzingen ter zake van materiële schade bedroeg $€ 3471$ euro, met een uitschieter naar boven van $€ 139.615 .{ }^{45}$

\footnotetext{
41. Zie voor verdere verantwoording en toelichting Kool e.a. 2016, p. 123-127.

42. Kool e.a. 2016, p. 139.

43. Kool e.a. 2016, p. 141.

44. Kool e.a. 2016, p. 147.

45. Kool e.a. 2016, p. 141.
}

\subsubsection{Kenmerken vordering vergoeding ander nadeel}

Vergoeding voor immateriële schade werd voornamelijk gevorderd vanwege lichamelijk letsel en antasting in eer of goede naam of vanwege persoonsaantasting op andere wijze. ${ }^{46}$ Daarbij geldt dat er geen correlatie is vastgesteld tussen de categorie als in artikel 6:106 BW en de toewijzing van vergoeding voor immateriële schade. Opvallend is een positief significant effect van een vergoeding voor enkel immateriële schade op de ontvankelijkheid. ${ }^{47}$ De hoogte van de gevorderde vergoeding voor immaterieel nadeel is gemiddeld $€ 1123$ en heeft geen effect op toewijzing van de vordering. ${ }^{48}$ Ook voor de vordering ter zake van immateriële schade geldt dat er een significant verschil is tussen de vordering en toegewezen vergoeding ten nadele van de benadeelde partij. ${ }^{49}$ De benadeelde partij die enkel vergoeding van immaterieel nadeel vordert en niet ook vergoeding van materiële schade is meer succesvol. Opvallend is verder dat de benadeelde gemiddeld een hogere vergoeding ter zake van immateriële schade vordert als die vordering met een vordering tot vergoeding van materiële schade gepaard gaat. ${ }^{50}$

\subsubsection{Verweer}

De verdachte die in het strafproces met een vordering van een benadeelde partij wordt geconfronteerd, verkeert, zoals bekend, in een lastige positie als hij er om welke reden ook voor zou willen kiezen in het kader van de strafrechtelijke procedure te zwijgen en dus ook geen verweer te voeren tegen de civiele vordering. De civiele vordering is immers in beginsel onderworpen aan de privaatrechtelijke regels ten aanzien van stelplicht en bewijslast. Aan die moeilijke positie is, zoals ook

\footnotetext{
46. Zie over shockschade recent Engelhard, Hebly \& Van der Zalm 2015.

47. Kool e.a. 2016, p. 139.

48. Kool e.a. 2016, p. 142.

49. Kool e.a. 2016, p. 142.

50. Kool e.a. 2016, p. 143
} 
Candido en anderen constateren, door de Hoge Raad tegemoetgekomen onder de overweging:

'Het is juist dat de aldus voorziene procedure aan de benadeelde partij en de verdachte niet dezelfde processuele waarborgen biedt als een gewone civielrechtelijke procedure. Hierin wordt echter in afdoende mate voorzien door art. 361 lid 3 Sv., welke bepaling in het licht van art. 6 lid 1 EVRM aldus moet worden uitgelegd dat zij de strafrechter tot niet-ontvankelijkverklaring verplicht indien hij niet verzekerd acht dat beide partijen in voldoende mate in de gelegenheid zijn geweest om naar voren te brengen hetgeen zij ter staving van de vordering, onderscheidenlijk tot verweer tegen de vordering kunnen aanvoeren en, voorzover nodig en mogelijk, daarvan bewijs te leveren. ${ }^{51}$

Met dat in het achterhoofd verbaast het wellicht niet dat uit het dossieronderzoek blijkt dat weliswaar in $82,4 \%$ van de gevallen waarin informatie over het verweer bekend was ook daadwerkelijk verweer is gevoerd, maar dat het verweer niet steeds erg uitgebreid was. ${ }^{52}$ In de meeste gevallen waarin nietontvankelijkheid voor de vordering ter zake van materiële schade werd gevorderd, is ter onderbouwing van dat verweer 'vrijspraak' aangevoerd. Ook het niet of onvoldoende onderbouwen door de benadeelde van zijn vordering is regelmatig als verweer gevoerd, net als het te weinig inzichtelijk maken van het vereiste causaal verband tussen de schade en het tenlastegelegde feit. ${ }^{53}$ Ook ten aanzien van de vorderingen ter zake van immateriële schade was het vaakst genoteerde verweer 'vrijspraak'. Verder zijn gerapporteerd noodweer, eigen schuld van de benadeelde partij en onevenredige belasting van het strafgeding. ${ }^{54} \mathrm{Bij}$ vier registraties is uit het vonnis gebleken dat rekening is gehouden met eigen schuld van de benadeelde partij. In drie gevallen werd de benadeelde partij niet-ontvankelijk verklaard. ${ }^{55}$ Voor zowel de vorderingen ter zake van materiële schade als die ter zake van immaterieel nadeel zijn geen significante verschillen ten aanzien van de ontvankelijkheid gevonden tussen het wel en niet voeren van verweer. ${ }^{56}$

\subsection{Factoren van invloed op de ontvankelijkheidsbeslissing: interviews}

\subsubsection{De interviews}

Ter versterking van de uitkomst van het dossieronderzoek zijn interviews afgenomen om te achterhalen welke factoren volgens personen die direct betrokken zijn bij de besluitvorming ten aanzien van de civiele vordering in het strafproces van invloed zijn op de ontvankelijkheidsbeslissing. Aan respondenten (rechters, officieren van justitie en advocaten) is tij-

51. HR 15 september 2006, NJ 2007/484, r.o. 3.3.2. En ook Candido e.a. 2013, p. 89.

52. Kool e.a. 2016, p. 148.

53. Kool e.a. 2016, p. 148

54. Kool e.a. 2016, p. 149

55. Kool e.a. 2016, p. 149.

56. Kool e.a. 2016, p. 149 dens de interviews daartoe een aantal factoren voorgelegd met de vraag of die van invloed zijn op de ontvankelijkheid. ${ }^{57}$

\subsubsection{Officieren van justitie}

Door respondenten werkzaam bij het Openbaar Ministerie wordt de aard van de schade als factor van invloed op de ontvankelijkheidsbeslissing genoemd. Toewijzing van immateriële schade wordt als een professionele gevoelskwestie ervaren. Een officier noemt $€ 1000$ als belangrijke grens wat dat betreft. Als een vordering die grens passeert, is er een aanzienlijke kans dat een niet-ontvankelijkheid volgt. Maar als oplossing wordt evengoed soms een voorschot toegekend en voor het overige niet-ontvankelijk verklaard. Het is dus een combinatie van de aard van de schade en de hoogte van de vordering die volgens (een aantal van) de officieren van invloed is op de ontvankelijkheid. ${ }^{58}$

\subsubsection{Rechters}

Rechters merken op dat de aard van de schade de ontvankelijkheidsbeslissing beïnvloedt. Vorderingen tot vergoeding van immateriële schade zijn volgens respondenten in deze beroepsgroep ingewikkeld. ${ }^{59}$ Illustratief wat dat betreft is de opmerking: '[A]ls je daar iets mee moet [met immateriële schade; JE \& RK], moet je echt gaan doorvragen: wat is er dan aan de hand geweest en waarom was het zo traumatiserend?' De moeilijkheid doet er niet aan af dat tegelijkertijd wordt gezegd dat rechters in strafzaken veel makkelijker zijn met het toekennen van vergoedingen voor immateriële schade dan civiele rechters. De een merkt daarbij op de gevorderde vergoeding wel regelmatig te hoog te vinden, terwijl de ander meent dat de toegewezen vergoeding in de jurisprudentie nog steeds erg laag ligt: 'Het leed is soms best groot, maar dat komt toch, in ieder geval in de beleving van slachtoffers denk ik, nog niet altijd tot uitdrukking in de hoogte van de vergoeding. ${ }^{\prime 60}$ Verder geldt volgens respondenten dat de ernst van het delict een rol speelt bij het al of niet voldoende onderbouwd zijn van de vordering ter zake van immaterieel nadeel. Dat wordt door een respondent als volgt onder woorden gebracht:

'Als het een relatief eenvoudig delict is en iemand zegt dat hij daardoor helemaal in de kreukels ligt en ernstig psychisch letsel heeft, dan zou ik denk ik toch eerder zeggen dat ik daar een verdere onderbouwing van wil zien, gelet op het vrij beperkte delict. Maar als iemand slachtoffer is van een gewelddadige woningoverval, dan is het erg voor de hand liggend dat je daarna geestelijk er slecht aan toe bent.' ${ }^{\text {'1 }}$

Respondenten uit de rechterlijke macht geven aan dat de hoogte van de vergoeding mogelijk de eerste reflex veroor-

57. Kool e.a. 2016, p. 170 e.v.

58. Kool e.a. 2016, p. 171

59. Kool e.a. 2016, p. 172.

60. Kool e.a. 2016, p. 172

61. Kool e.a. 2016, p. 172. 
zaakt, maar dat die niet doorslaggevend is. ${ }^{62}$ Een hoog schadebedrag hoeft anders gezegd niet tot een onevenredige belasting van het strafgeding te leiden. Rechters zeggen voor de omvang van de vergoeding van immaterieel nadeel verder ook wel naar de Smartengeldgids en de lijst van de Letselschaderaad te kijken, als richtsnoer. Maar één rechter stelt expliciet dat het uiteindelijk toch vooral een gevoelskwestie blijft: '[W]e doen allemaal wat we redelijk vinden en redelijkheid is een heel vaag criterium.' $^{63}$

Verweren, tot slot, zijn volgens deze respondenten belangrijk, zeker naarmate ze meer gemotiveerd zijn. Als verweren hout snijden en aanleiding zijn voor een civielrechtelijke discussie, ligt een onevenredige belasting op de loer. Er is dan vaak aanleiding voor bewijsopdrachten en dat is te belastend. Maar er wordt ook gezegd dat de kennis van de strafrechter wat dat betreft niet ver genoeg reikt. ${ }^{64}$

\subsubsection{Advocaten}

Volgens advocaten zijn hoge vorderingen tot vergoeding van immateriële schade aanleiding voor moeilijkheden. Tegelijkertijd geldt volgens deze respondenten, en dat is in lijn met wat daarover door rechters is gezegd, dat naarmate een delict ernstiger is, minder snel een niet-ontvankelijkheid wordt aangenomen. ${ }^{65}$ Over materiële schadeposten zeggen advocaten dat die eenvoudiger tot ontvankelijkheid leiden, omdat dit type schade aan de hand van bijvoorbeeld bonnetjes gemakkelijker kan worden aangetoond. ${ }^{66}$ Volgens advocaten is de vordering tot vergoeding van immateriële schade er overigens ook bij gebaat als tegelijkertijd vergoeding van materiële schade wordt gevorderd die in direct verband staat met het immateriële nadeel. Daarbij kan bijvoorbeeld worden gedacht aan therapiekosten. Deze opmerking sluit aan bij de bevinding in het dossieronderzoek dat er een significant hoger bedrag aan vergoeding van immaterieel nadeel wordt gevorderd als er ook een materiële schadepost is aangevoerd dan in de situatie waarin niet tevens een materiële schadepost is aangevoerd. ${ }^{67}$ Onderbouwing van het immateriële nadeel door de advocaten gebeurt overigens met behulp van de Smartengeldgids en door verwijzing naar zelf geselecteerde jurisprudentie. De Smartengeldgids zou overigens niet zoveel zeggen, horen advocaten terug vanuit de rechterlijke macht. ${ }^{68}$ Advocaten noemen verder nog toekomstige schade als schadepost die (relatief) gemakkelijk tot niet-ontvankelijkheid aanleiding geeft. ${ }^{69}$

In lijn met opmerkingen door respondenten uit de rechtspraak zeggen ook advocaten dat een goede inhoudelijke discussie over de vordering tijdens de zitting de kans op niet-ont-

62. Kool e.a. 2016 , p. 173

63. Kool e.a. 2016, p. 173.

64. Kool e.a. 2016, p. 173.

65. Kool e.a. 2016, p. 174.

66. Kool e.a. 2016, p. 174.

67. Kool e.a. 2016, p. 143. Zie ook par. 4.2.3.

68. Kool e.a. 2016, p. 174-175.

69. Kool e.a. 2016, p. 175. vankelijkheid vergroot. ${ }^{70}$ Advocaten zeggen over verweren tegen de civiele vordering ook nog dat bij geen verweer sneller een toewijzing volgt, óók als het gaat om een omvangrijke vordering tot vergoeding van immateriële schade. Tegelijk wordt een zekere koudwatervrees bij rechters waargenomen om hoge vergoedingen voor immaterieel nadeel toe te kennen; de rechter zou in dergelijke gevallen de neiging hebben tot gedeeltelijke toewijzing. ${ }^{71}$

Meer algemeen hebben advocaten soms de indruk dat rechters en officieren 'vrij snel geneigd zijn' om geen tijd in de vordering te stoppen. ${ }^{72}$ Een advocaat stelt ook dat rechters zich niet altijd realiseren hoeveel tijd, energie en geld het een benadeelde kost om hun schade (vervolgens) bij de civiele rechter te verhalen. Er wordt bovendien gerefereerd aan de emotionele belasting die het bewandelen van die andere weg vervolgens kost. Daarbij geldt dat er bij het vervolgens instellen van een civiele procedure wel sprake moet zijn van een slachtoffer 'die nog wel redelijke stevig in de schoenen staat (...). Want al die argumenten die civiel nog eens extra kunnen komen kijken, daar moet je ook weer net tegen kunnen. ${ }^{73}$ Een andere respondent merkt hierbij aansluitend op dat het voor slachtoffers van belang is dat ze 'maar één keer met zo'n strafzaak bezig zijn' $^{74}$

\subsubsection{Andere knelpunten}

Gevraagd naar (andere) knelpunten en oplossingsrichtingen valt op dat zowel in de groep respondenten vanuit het Openbaar Ministerie als in die uit de rechterlijke macht knelpunten worden gesignaleerd in de toenemende slachtofferparticipatie. 75 Officieren van justitie spreken over toenemende slachtofferparticipatie en de tijdsdruk bij de voorbereiding en behandeling van het civiele schadeverhaal. Een respondent stelt, gevraagd naar een oplossing, voor om de vordering na de uitspraak in de hoofdzaak door een civiele rechter te laten beoordelen. ${ }^{76}$ Rechters wijzen op de mogelijk problematische uitwerking van de uitbreiding van de slachtofferrechten. Een respondent merkt op dat de vraag hoe het allemaal in het strafproces kan - praktisch - 'een ondergeschoven verhaal' blijft. ${ }^{77}$ In de zorgen over de slachtofferparticipatie wordt ook het uitgebreide spreekrecht betrokken, waarbij respondenten zich afvragen of de veranderingen uiteindelijk in het voordeel van het slachtoffer zijn. ${ }^{78}$

\subsection{Civiel schadeverhaal anno 2016}

Uit het onderzoek blijkt aldus dat de houding van de strafrechtspleging ten aanzien van het civiele schadeverhaal via het strafproces anno 2016 anders is dan voor de invoering van het 
nieuwe ontvankelijkheidscriterium. Die verandering wordt door de strafrechtspleging echter niet zozeer toegeschreven aan het nieuwe, verruimde ontvankelijkheidscriterium, maar aan de tijdgeest en aan de gewenning aan het slachtoffer in het strafproces. Die veranderde tijdgeest heeft positieve, maar ook minder positieve veranderingen in het strafproces gebracht.

Tot de positieve veranderingen rekenen wij (vanzelfsprekend) in de eerste plaats het minder snel niet-ontvankelijk verklaren van de benadeelde partij, zoals blijkt uit de trendgegevens, maar ook de concrete praktijkvoorbeelden die in de interviews naar boven kwamen ter illustratie van de stelling dat er wel degelijk iets is veranderd, bijvoorbeeld van rechters die stelden dat de hoogte van de gevorderde vergoeding tegenwoordig toch minder snel aanleiding is om niet-ontvankelijk te verklaren.

Een belangrijk minder positief gevolg van de veranderde tijdgeest betreft de rol van het slachtoffer in het strafproces. Met de toegenomen (aandacht voor de) rechten van slachtoffers wordt het managen van de verwachtingen, maar ook het bewaken van de balans tussen de strafvordering en de (accessoire) civiele vordering moeilijker. Daarbij komt dat de tijd die is gegeven voor de voorbereiding en behandeling van strafzaken beperkt is en de voorbereiding en behandeling met de grotere rol van het slachtoffer dus voor grotere druk zorgen.

\section{Uitleiding}

Civiel schadeverhaal is tegenwoordig een bekend en niet weg te denken onderdeel van het strafproces. Bekend en niet weg te denken, maar niet volmaakt. In het onderzoek waar hier verslag van is gedaan, zijn de rechtspraktijk en regelgeving ten aanzien van dat schadeverhaal verkend met de bedoeling te zien of veranderingen ten aanzien van het civiele schadeverhaal die zich de afgelopen jaren hebben voorgedaan (onder meer de wijziging van het ontvankelijkheidscriterium in 2010), hebben bijgedragen aan het bevorderen van het civiele schadeverhaal via het strafproces. Deze verkenning volgt op eerdere, soortgelijke studies, in het bijzonder die door Van Wingerden en anderen, waarin een vergelijkbare vraag centraal stond. ${ }^{79}$

Het onderhavige onderzoek leidt in de eerste plaats tot de conclusie dat er sinds de studies van Van Wingerden en anderen veel is gebeurd en verbeterd. Zo heeft een belangrijke stroomlijning in het (hier kort genoemde) voortraject plaatsgevonden die bijdraagt aan een betere voorbereiding van het civiele schadeverhaal. Daarnaast is gebleken dat de kans op een ontvankelijkheid in de loop der jaren is toegenomen. De meeste voor dit onderzoek geïnterviewden (rechters, officieren van justitie en advocaten) schrijven een verandering in de rechtspraktijk echter niet toe aan de wijziging van het ontvankelijkheidscriterium in 2010. Verschillende respondenten signaleren wel een (positieve) ontwikkeling op het gebied van het civiele schadeverhaal, maar menen dat die eerder het effect is van 'besefvorming' en 'de tijdgeest'.

Tegelijkertijd zijn er evengoed door Van Wingerden en anderen gerapporteerde uitkomsten onveranderd gebleven. Dat is bijvoorbeeld het geval ten aanzien van de gevoerde verweren. Gelijk aan de conclusie van Van Wingerden en anderen is in dit onderzoek vastgesteld dat de kwaliteit daarvan vaak te wensen overlaat. Die uitkomst laat zich verklaren, zoals ook Van Wingerden en anderen opmerken, door de moeilijke positie waarin de verdachte verkeert die zich in het strafproces met een civiele vordering geconfronteerd ziet. Rechters en officieren zijn zich hier terdege van bewust en bieden wat dat betreft tegenwicht door een meer actieve opstelling. Er is dus sprake van ontwikkeling, maar ook van aandachtspunten die onveranderd om aandacht vragen.

79. Van Wingerden, Moerings \& Van Wilsem 2007. 